\title{
Being Away from Home in Australia: The Indonesian Diaspora in Canberra
}

\author{
Wasisto Raharjo Jati \\ The Indonesian Institute of Sciences \\ Email: wasisto.raharjo.jati@lipi.go.id
}

\begin{abstract}
The study of diasporas has been given relatively little attention by Indonesian scholars. A likely reason is the high cost of funding diaspora research in the host countries, motivating scholars to instead focus on other, less resourceintensive topics. Although the significance of this research on the Indonesian diaspora may not be immediately evident, its importance lies in how Indonesians maintain their nationalism when living overseas. Two problems particularly felt by them are homesickness and anxiety. Using an ethnographic approach, this research therefore sought to highlight how the Indonesian diaspora based in Canberra, Australia, make social bonds with each other. These bonds serve to make Canberra a second home for Indonesians, especially students and their families, permanent residents, and even naturalised citizens who have Indonesian backgrounds. A main finding was that there are various senses of Indonesianess between groups in the Canberra-based diaspora. While students are much more likely to maintain a feeling of nationalism due to scholarship policies, other groups in the diaspora, such as permanent residents and naturalised citizens, appear to hold onto their Indonesianess less tightly. Although they still engage with Indonesia, they view the country more critically, including on sensitive issues that are labelled as taboo in Indonesia. Despite the existence of these two different conceptions of Indonesianess, Canberra is their home away from home in Australia. These results consequently aid in our understanding of the significance of family ties to shaping most Asian diaspora communities living abroad.
\end{abstract}

Keywords: Australia; Canberra; Indonesian diaspora; naturalized citizens; permanent residents; sense of Indonesianess; students

\section{INTRODUCTION}

Diasporic people always have mixed feelings while living abroad. They are often keen to follow current affairs in their home country. however, they also can ignore it because they have adapted to the new environment. This initial ambivalence of feeling is common among diasporic people. Another issue is diasporic people also tend to stay closely connected with their fellow countrymen. They will occasionally organise social events which involve others from their country of origin. The main aim of the events is uniting the same people and preventing homesickness. In short, social groups nurture an orientation toward home when living overseas. These feelings are about social and emotional relationships with the home country.
The focus of this paper is to examine these feelings. In the literature on this subject there are several existing empirical studies which highlight home-oriented feelings. One authoritative study by Michel Bruneau reveals that home memory plays an essential role in shaping a community bond in the host country (Bruneau, 2010:36). More importantly, he emphasises "the term 'diaspora' often plays more of a metaphorical than an instrumental role" (Bruneau, 2010:36). Similar to previous studies, the importance of the metaphorical role can be available when it comes to dual identities (Wofford, 2016:76). This metaphor simply means the experience of dispersal makes the diasporic community produce feelings of home 
slightly different to their fellow expatriates.

While still connected with the home country, the diasporic community can also be more open-minded and critical towards it. The findings of the two diasporic empirical studies basically show how the diaspora can be analysed from different viewpoints. This also relates to the most appropriate methodological approach. The diaspora studies are the specific case because it depends on different migrant people living in their chosen host countries. This topic draws upon different social science disciplines including political science, international relations, history, and law in researching diasporic people. However, these three social sciences disciplines tend to focus on macro issues such as citizenship, migrant workers, and political exiles in a framework of interstate relations rather than the individual human subject. Based on this a research gap is micro analysis such as diasporic daily life in the foreign environment and how they build their own normal activities as they used to when living in their home country. Such research can provide an interesting and complementary story in diasporic studies. Given the research object is at the micro level, ethnographic research is the most suitable method for this type of study.

This paper seeks to answer the following research questions: what is the most suitable method to determine the home social orientation in diasporic people. This question addresses two specific issues 1) how to approach the diasporic group in order to collect the data, and 2) how to sit in on two or three diasporic groups based on their identity affiliations. This paper argues ethnography is the most appropriate method for analysing the home orientation feelings of Indonesian diasporic people in Canberra. Firstly, the paper discusses previous diaspora research which includes how researchers use certain methods. Secondly, it introduces this research project and its methodological approach. Thirdly, it explains the reasons why this ethnographic research is the best method for this type of project. This also includes justifications and possible limitations of these research method.

\section{PREVIOUS DIASPORIC RESEARCH}

There are quite a number of current studies on diaspora. The first type of study relates to transnationalism movements while the second focuses on migration. The first takes examples of Jewish, Kurdish, and Palestinian communities and their homeland oriented feelings (Kranson, 2012; Gruen, 2016). The second focuses on the life of migrant people in the host country, particularly developed countries (Nurse, 2018 ; Sinatti \&
Horst, 2014). In regards to these two types of diasporic studies require multidisciplinary understandings, which not only different in terms of their thinking but also in their methods. There are three approaches with different research methods in diasporic studies. There is an historical approach with library and archival research, the comparative political approach with content analysis, and the sociology of law approach with tracing analysis, which shows causal relationship between two objects within empirical situations. These three approaches have produced different research results in diasporic studies.

An historical analysis approach treats diasporic people as the subject. As a result, it perceives diasporic people as an actor rather than part of the system. This approach focusses on the diasporic relation as one of home and host state. The comparative political analysis approach treats diasporic people as part of a system and integral with the state. This understanding focuses on how the government treats the diasporic people as citizens. In this sense, this approach demands a comparative analysis of governments' policy impacts on the diaspora.

The sociology of law approach treats diasporic people as heterogenous actors. This interdisciplinary approach perceives diasporic people as social actors and also a subject of law. Therefore, the main research focus of this approach is the legal status of diasporic people. Citizenship and how the host country people accept diasporic people as new citizens is the main object of the research.

Robin Cohen and Gabriel Shaffer are scholars who use comparative historical analysis to studying a diaspora. In his research, Robin Cohen defines 'diaspora' as an expatriate minority community(Cohen, n.d.:507). Cohen uses archived documentary sources to uncover past diaspora research. His main motivation is to find out the common features of diasporic people. According to his findings, there are four common features of a diaspora (Cohen, n.d., p. 508). The first feature is the departure from a homeland in search of work and in pursuit of study overseas. The second feature is the collective memory of and emotional relationship with the homeland. Third, is the sense of empathy and solidarity with the same ethnic diasporic members. The fourth feature, is the lack of cultural and societal acceptance from the host country. These four features describe the way of life among diasporic groups overseas. This condition also explains a need for recognition from their fellow countrymen after going overseas, and the strong internal connection among their diasporic peers while living in a foreign country. Both findings eventually lead to the hypothetical argument: the greater the attachment to other 
diasporic members, the stronger they feel about home and their identity.

In this case, Cohen's work provides an understanding of the common situation diasporic people having been facing. However, the explanations can be too general as opposed to delving into the variety of contexts and situations. Whereas in fact the diasporic people can be regarded as heterogenous with a range of distinctive experiences. The more significance is that his work gives little attention to explaining home orientation feelings.

Unlike Cohen, Gabriel Shaffer uses comparative political analysis to undertake diasporic studies. He does content analysis based on textual diasporic information in selected countries data. He argues a diaspora tends to maintain close relations with their homelands due to strong ethnic, national, and -religious factors (Sheffer, n.d.:14 15). These factors show the partial integration of diasporic people in host countries. Precarious environments and hostile views persuade diasporic people to engage closely with their fellow countrymen. Another important factor is the voluntary return to their homeland (Sheffer, n.d.:17). These three explanatory arguments shape social diasporic bonding overseas.

Schaffer also argues a diasporic community tends to pursue an isolationist position in order to maintain their social boundaries with foreign people in the host country (Sheffer, n.d.: 21). In addition, this policy includes establishing organisations or regular meeting fora to show their existence and loyalty to the homeland. In this context, diasporic organisations help them to interact without any social barriers. The diasporic organisation comprises several identities such as religious and ethnic affiliations. Therefore, diasporic people remain loyal to their national and local bonding as they used to do in the home country.

A methodological limitation in Schaffer's approach is he does not employ in-country or comparative country case studies to strengthen his arguments. While he mentions at random Jewish, Basque, Armenian, Kurdish, and Albanian diasporas, he does not go on to make sense of' the current bilateral relationship between the specific homeland and the host lands in diasporic]life (Sheffer, n.d.:23). In the case of the Albanian diaspora for example, it is not exclusively Albania as a single nation, but is also composed of scattered Albanian groups in several Balkan countries. It is similar to Kurdish ethnic groups that are dispersed in Turkey, Iraq, and Syria. Given the diverse host countries of the diasporic communities it is probable that there are different home feelings across these communities.

Rubin Patterson uses a sociology of law approach in diasporic studies. He traces collective and emotional memory as the foundation of homeland feeling. In addition, he also examines legal documents about citizenship. Rubin Patterson argues diasporic people can contribute to national development processes in the country of origin by transferring knowledge and capital (Patterson, 2006:1897-1899).. Furthermore, the countries of origin maintain close relations with their diaspora in order to benefit from their intellectual capital. Countries also allow flexible dual citizenship to some degree to their diasporas who would like to return home (Patterson, 2006:1897-1900). Patterson, based on this research, recommends flexible citizenship for diasporic people. The idea is for diasporic people to be able to enter the home country without a visa not clear, do you mean 'rather than being treated as a foreign citizen'. Therefore, they still preserve a home orientation feeling. In his research, Patterson traces Indian, Israeli, Korean, and Sub-Saharan diaspora living in the United States from their first arrival in US until building a connection with their host country.

The methodological limitation in his research is the reliance on legal documents such as citizenship or legal bilateral agreements. Although the use of legal documents enables an alternative view to be developed in diaspora studies, it does not permit the study of internal diaspora relationships. The official demographic records are the most interesting factor how they survive in foreign environment. The use of tracing analysis in Rubin's research requires skilled analysis to ascertain strong diasporic tendencies derived from many documentary sources particularly legal agreements and population census reports. However, he provides very few technical explanations as to how tracing analysis is applicable to his research. Rubin concludes that in order to solve home orientation feelings there needs to be flexible citizenship. However, His conclusion of this need for flexible citizenship however, linked to an economic orientation rather than a home orientation, needs further substantiation.

Compared with previous research, which is largely based on secondary data, Brocket does active participatory research in diasporic studies. He uses ethnographic research in several diasporic Palestinian groups in the US. This research also covers how they build social connection between homeland and diaspora community. In addition, he also uses coding analysis based on open structure interviews (Brocket, 2018:3). From this research, there are two interesting findings. First, the Palestinian diaspora particularly the secondgeneration often experiences a sense of not being fully American due to biological factors such as dark skin or 
curly hair (Brocket, 2018:8). At the same time, they are also "too American" in the eyes of Palestinian national (Brocket, 2018:9).

Second, this second-generation acknowledges an ambivalence in belonging. While they truly admit their Palestinian ancestry through a hereditary family line, the second generation is also a racists and diasporic group through a western upbringing method in US society (Brocket, 2018:14). This dilemmatic situation shows diasporic people are in challenging situations in their relationship to their host country and home land. Furthermore, the Palestinian diaspora is unable to express their home orientation feelings in both Palestine or US. Due to their hybrid identity, the definition about 'home' is blurred in their mind,

Tom Brocket worked for eleven months on both fieldwork research in New Jersey,US and the West Bank, Palestine. He lived in with several diasporic groups and stayed close to the targeted respondents whom he calls "interlocutor". He also used pseudonyms for respondents. After collecting the data from respondents, he analysed them in NVivo to do coding analysis (Brocket, 2018:3). This process enabled him to extract the data precisely without having a subjective view of the research objects. However, in this methodological matter, he does not explain how to code the data through NVivo software. This would give basic software knowledge for other researchers who would like to conduct same ethnographic research.

From these diasporic studies, there are some apparent methodological problems. First, there is no view from within the diasporic groups, all the researchers are outsiders who have not engaged with certain diasporic groups. This matter certainly brings consequences about different interpretation of the results in viewing diasporic people. The outsider researchers often produce diaspora studies just on the normative issues because they are ethnically or racially different with their research subject. As a result, they just extract the data from secondary documents. Second, potential biased observations and data interpretations. Both issues relate to the way researchers interpret the secondary data without having face to face meeting with respondents. Consequently, they may get distinctive sense yet is opposed to the real diaspora situation. Third, all the previous researches do not provide enough explanation about home orientation feelings. All the researchers to date mostly focus on identities discrimination, citizenship problems, and state immigration policy. Arguably these results do not touch grounded diaspora problems such as how they tackle homesickness, how they build social bonding, and how they maintain relations with home land.

Based on this review of the research, ethnography research is the most appropriate for diaspora studies. While diasporic study is an extensive field obtaining data from insiders. Another consideration is active in-group or personal participation to enable in-depth knowledge. The researchers certainly can gain valid data from the respondents. This is the most important thing, to gain primary data first of all rather than counts on secondary data. Because the researchers can gain more complex information from their fieldwork. All of these considerations lead to ethnography research as the most appropriate method to use in diaspora studies.

\section{PREVIOUS INDONESIAN DIASPORIC RESEARCH}

Previous Indonesian diasporic research concentrates on three major topics namely, political exile overseas, migrant workers, and dual citizenship issues. Therefore, the most common approaches in these studies are history, political science / international relations and law. It is important to note, the term 'diaspora' used is the recent definition being used by the Indonesian government (Setijadi, 2017:1). Previously, the government used the term 'overseas citizen' because the state just focused on Indonesian passport holders rather than those of Indonesian descent living overseas. After the Indonesian diasporic congress, the government began to accommodate the diaspora using it for in particular economic matters (Setijadi, 2017:7 $\& 12)$.

These three approaches emphasise the role of the state in managing its diasporic people. Sometime the Indonesian diaspora topic also involves bilateral and multilateral actors because of political aspects and legal agreements. As a result, there is little research on the Indonesian diaspora focussed on home orientation feelings.

Political matters featured prominently after the failed 1965 coup. Many Indonesian leftists who were living in communist states abroad became exiled after the government revoked their passports. David Hill, a prominent Indonesian studies scholar, use the historical comparative analysis to examine the Indonesian diaspora in Russia. He did archival research by examining telegrams, message memos, and Indonesian embassy reports. He argues the Indonesian diasporic group gained helps from communists in host communist countries (Hill, 2014:632-633). As a result, the new Indonesian regime could not repatriate them to home. Hill's research arguably describes home orientation feelings such 
homesickness and anxiety after becoming stateless. But he pays attention to international leftist solidarity which helps the Indonesian leftist diaspora. In this context, ideological orientation feelings are more relevant than home orienting feelings in David Hill's research. The methodological limitation from his research is he does not complement these archival sources with other data from government and the Indonesian diaspora leftists. As a result, Hill's research results are likely one-sided findings in diaspora research.

The second and third Indonesian diasporic studies relate to how the state exercises protection over its overseas citizens. However, the third issue involves those of Indonesian descent as the main unit of analysis. In this context, the migrant worker has become a recent topic of debate with stories of migrant worker sexual harassment and physical torture featuring prominently in the press (Silvey, 2004: $249 \&$ 258). The third issue is deals with the issue of dual citizenship in responding to increasing globalisation. The first Indonesian diasporic congress was the main trigger to propose dual or flexible citizenship for overseas Indonesians (Dewansyah, 2019:54-58).

Legal research has been on migrant worker and citizenship issues in Indonesian diaspora studies. The main unit of analysis mostly requires case-by-case criminal reports or critical judicial reviews. In this regard, legal research does not view the human subject, but rather state policy subject. Also, the researchers mostly use secondary data such as legal documents. In this sense, researchers extract information about the diaspora at a surface level but arguably do not study Indonesian diasporic people at the grass roots level. Consequently, home orientation feelings are not the primary focus in Indonesian research to date.

In sum, previous Indonesian diaspora research has employed historical and legal research. It mainly uses comparative historical analysis and content analysis to extract data from secondary information. The shortcoming here is the same as global diasporic research, the use of secondary data is used to make the main arguments with the data drawn from official legal documents. As a consequence, the research results describe normative issues rather than real-world issues. More precisely, the research is takes as its object diasporic policies rather than Indonesian diasporic people.

Given the research object is at the individual level, ethnography presents as the best method in analysing the diaspora. In this project, the method requires close interaction with diasporic people for an extended period of time in order to gain relevant data. The informants are treated as active human subjects and the interaction sought is when they are acting naturally in normal daily life. This is regarded as the most important factor in order to obtain reliable information, particularly home orientation feelings. This is underpinned by the assumption that through ever closer engagement with them more information will be offered about their feelings.

\section{METHODOLOGICAL APPROACH}

In line with these considerations above, ethnographic research is used in this project. The main purpose being to 'get an inside view' as to the way each group of people sees the world (Reeves \& Ayelet, 2008:512). This inside view includes detailed information from the respondents such as fluctuating internal relationship, how they struggle with different circumstances while being far away from home, and how they perceive and define their social boundaries in Canberra. All these questions are within the scope of what is observed through the ethnographic approach.

According to ethnographic tradition, there are three approaches, namely: auto-ethnography, metaethnography, and online ethnography (Reeves \& Ayelet, 2008:512). The first approach means the researcher defines the interpretation of the research object. This researcher also builds up knowledge after gaining field data. It also emphasises the researcher must investigate secondary data in books, reports, journals, and other relevant documents. In this sense, the researcher tries to determine the causal links between the data in the documents to extract the knowledge. A further aspect using on online meetings on social media. This kind of ethnographic research is a new development. The researcher can thus considerably cut their research field period compared to usual ethnographic research method.

For this paper auto-ethnography is the main method used. The main reason for this is that it allows the free construction of the findings from field research. Nevertheless, a literature review is also conducted noting that research findings alone are insufficient for an academic report. The literature review provides supporting data from previous research in order to strengthen field data. Online ethnographic research however, is less relevant because there is ready face to face access to several Indonesian students on their campus.

The ethnographic research is conducted by being actively involved in several targeted diasporic communities. From these communities, two diasporic communities were chosen, one centred on Islamic teachings (pengajian) and the other alumni networking. 
Informants were chosen who had a close relationship with the researcher through offline informal conversations and online social media platforms particularly, WhatsApp. These snowballing methods enabled contact with more informants, which allow data and information to be filtered from each respondent. The respondents were asked about daily life issues such as school and family life. These two topics yielded fruitful data for example, how they forged social bonding within the Indonesian diaspora and how they maintained connections with the home country. This method had been used previously by the researcher when doing ethnographic research to capture life histories in other field work. While this method does produce more data, at the same time it leads to engaged with the informants' experiences however, subjectivity was avoided by using question lists.

The ethnographic research method is suitable for this type of research project because it allows the researcher to have daily informal conversation in groups. More importantly, this method puts the informant at ease which facilitates obtaining the data from this type of fieldwork. Ethnography method means not treating the researcher as the knowledgeable person and the respondent as the passive subject. Both actors are equal and contribute to knowledge production. The writer rather than being treated as researcher doing fieldwork sought to be accepted as a part of the diasporic group. This meant keeping interactions as normal as possible during the research period. The writer, as a consequence of previous fieldwork experience, sought to avoid a repetition of a situation where the respondents would act strangely because they were in the presence of a researcher.

Ethnographic research is arguably more about practice than method. Of note is doing this research does not require the researcher to follow strict guidelines. This method treats the researcher, respondents, and the supporting social circumstances as occurring in normal and natural conditions. Both conditions will enable the researchers to gain in-depth data through face-toface interactions. According to O'Rielly, ethnographic research practice involves participant observation, indepth interviews, and conversations (O'Reily, 2004:23). All these three practical activities show ethnography research is not merely observing the static object but also a dynamic life system. This makes ethnography particularly useful because it enables an active interpretation of human beings and their supporting system. More importantly, the human subjects studied reflect the societal structure they live in. They also face normal opportunities and constraints hence doing ethnographic research means a mirroring of the researcher during the research period.
The second explanation for doing ethnographic research is not to predetermine the cause and effect of certain theories in society. These arguments mean the researcher should be no distance with the human subjects. Because ethnography research strongly emphasises inductive learning rather than a top-down approach. In addition, inductive thinking also helps the researcher to enjoy every process and challenges during the fieldwork. As a result, new theories or revision the existing theories.

Although ethnography research is more flexible and feasible to extract data and interpret the findings this type of research method also has some limitations. The first limitation is way data is presented rather than data reliability. There are those who argue this way of reporting data is not widely accepted in academia because the report should be objective with supporting evidences (Hammersley, 2006: 8-9). The second limitation is that there is no academic framework. As mentioned earlier, an inductive approach enables researchers to think holistically rather than theoretically therefore, the result is more like a novel than an academic report.

\section{FINDINGS AND DISCUSSION}

This research project investigates the Indonesian diasporic communities who live in Canberra, Australian Capital Territory (ACT). This diasporic membership consists of single students, postgraduate students with their families, permanent residents, embassy staff and their dependants, and Indonesian Australians. According to the data from the Canberra-based Indonesian voters' database in the 2019 general election, there are roughly 1212 people $^{1)}$. However, it is important to note, this number does not include Indonesian Australians. The reason is because they are naturalised Australian citizens therefore, they were ineligible to cast a ballot during the last election at the Indonesian embassy. Despite not being Indonesia citizens by law, they still follow diasporic Indonesian communities' activities. This is the way of Indonesian Australians to never forget their ancestral roots.

The home orientation feelings examined are social bonding shown in regular meeting fora, their subnational consciousness found in sharing similar religion and ethnicity, and strong internal relations such living in the same shared house or same suburb in Canberra. Here home orientation feelings is defined as the way people replicate an Indonesia situation while living overseas. This is part of emotional efforts to maintain a relationship with Indonesia.

For this research project, student groups are categorized as a temporary diaspora while other diasporic 
groups are categorised as a permanent diaspora. This classification of Indonesian dispora groups is following their stay period in Canberra. This separation of groups enables an examination of their level of Indonesianess exhibited while living in a foreign country. Another reason for this grouping is to examine their cohesiveness as a diasporic people in certain groups. The expectation is student groups are closer to specific diasporic forum and more attached to Indonesia than non-student groups. The reason is related to short term stay in the diaspora thus their connection with Indonesia is stronger than those in the permanent diaspora. Consequently, they are not adapting too much to western culture during their study for example, they often mingle with Indonesians only rather than other international students. This behavior gives a sense of their inward-looking views rather than embracing global culture.

According to the Canberra-based Indonesian Student Union database, there are six main Indonesian groups namely, student groups, Indonesian campuses alumni, extra-curricular education, religious affairs, ethnicities, hobbies, and employee sector (ACT, n.d.). These six main categories then have sub-categories who have a range of membership numbers. The table below shows the population of these Indonesian diasporic groups in Canberra.

Table 1 shows different sub-groups below the main themes. Some groups do not have a chairperson because they are just informal communities of interest, rather than a formal organisation. However, for student and alumni associations, they are more likely to have an organising committee. The reason behind this is because there is a building of networks after campus life. They still maintain social bonding when back home in Indonesia. It is important to note, one diasporic Indonesian can actively participate in more than one group. It means this person has multiple identities or interests in different groups for example, someone who previously joined a certain religious group could also participate in a hobby group. The role of the coordinator is important here. For nonstudent and alumni groups, they have agreed to appoint one or two coordinators to handle social activities. This coordinating role is voluntary, but it has an impact on how they lead their own diasporic groups. All this table information I have updated a bit to show the current committee.

All these groups arguably have different level of diasporic cohesiveness and home feelings. Both issues will lead to an understanding of how deeply each ingroup interacts and how they express their home identity feelings. One possible reason is the frequency of social meetings. The more they meet each other, the more social bonding there is. Another possible reason is joining in one or two groups allows them to manage anxiety and home-sickness. Indonesian diasporic members often suffer loneliness and stressful experiences while living in a foreign environment. Belonging a diasporic group therefore, gives them a new Indonesian family during their stay in Canberra.

In sum, to examine the Indonesian diasporic situation in Canberra, an active participatory approach is needed. The reason is because each diasporic community has distinct conditions. Participating in one or two targeted groups enables an understanding of the dynamic and vibrant interaction among members. Another reason is the respondents are more likely to trust the researcher if sharing a similar identity. It is worth noting, shared identities play important roles in shaping mutual building of trust in diasporic groups. Both reasons support the view that ethnographic research is the best approach to investigate Indonesian diasporic groups in Canberra. Arguably the most important reason is, given that the researcher is a member of a number of a number of diasporic groups there is existing access to data from respondents.

As mentioned above, being able to have informal daily conversations is the main reason for selecting an ethnographic approach. main approach to interpret data. Apart from conversations, other practical ethnographic data comes from physical observation and online observation. For the latter, this kind of ethnography data I use to enhance my observation findings.

An ethnographic approach has some advantages and disadvantages. An advantage is ethnographic research does not require sophisticated research skills nor following strict guidelines. Also, it does involve considerable expense to hire research assistants. There are also no language and cultural barriers in dealing with Indonesian diasporic people given the matching background of the researcher. Another advantage being the sole authority to construct the findings in an academic report. Everything data is important in this approach. In this sense, the common rumours among Indonesian diaspora still relate to domestic affairs in home country because they still keep-in-touch with any issues related Indonesia from various Indonesian-based online news portal. In sum, these advantages mean the researcher can present naturally as being a part of the diaspora.

A disadvantage of this approach is the data comprises mostly daily stories meaning its reliability and accuracy is brought into question. Also, the researcher's own feelings intrude when interviewing the respondents 
Table 1. Indonesian Diasporic Groups in Canberra

\begin{tabular}{|c|c|c|}
\hline No & Name of Diasporic Group & Chairperson \\
\hline \multicolumn{3}{|c|}{ Student Groups } \\
\hline 1 & Indonesian Students Union in ACT (PPIA ACT) & Joshlyne Tasek \\
\hline 2 & University of Canberra Indonesian Student Society (UCISS) & Bisuk Marshan \\
\hline 3 & ANU Indonesian Student Association (ANUISA) & Muhammad Iqbal \\
\hline \multicolumn{3}{|c|}{ Indonesian Campuses Alumni Networking } \\
\hline 1 & Universitas Gadjah Mada (UGM) Alumni Family (KAGAMA), Canberra Chapter & Wasisto Raharjo Jati \\
\hline 2 & Bandung Institute of Technology Alumni Association, Canberra Chapter & Umar Hanif Ramadhani \\
\hline 3 & $\begin{array}{l}\text { Alumni Association of Faculty of Economic and Business, University of Indonesia, } \\
\text { Canberra Chapter }\end{array}$ & Joseph Marshan \\
\hline \multicolumn{3}{|c|}{ Extracurricular Education Service } \\
\hline 1 & The Australian Indonesian-Language Schools Association (AILSA) & \\
\hline 2 & Perisai Diri Canberra / Indonesian Martial Arts Association & \\
\hline 3 & Quran Teaching for Muslim Children & Hanif Rasyidi \\
\hline \multicolumn{3}{|c|}{ Religious Affairs } \\
\hline 1 & Australia Indonesia Muslim Foundation in ACT (AIMFACT) & Imam Malik \\
\hline 2 & Khataman Canberra (Indonesian moderate Muslim group) & Katiman \\
\hline 3 & Pengajian Keluarga (Indonesian conservative Muslim group) & Abrar Yusuf \\
\hline 4 & Indonesian Christian Society Association & Yama Radimin \\
\hline 5 & Indonesian Catholic Community & Dian Indraswari \\
\hline \multicolumn{3}{|c|}{ Ethnicities } \\
\hline 1 & HORAS Canberra (Batak People's Association) & Jerry Marmen \\
\hline 2 & Aceh Australian Society (Acehnese people Association) & \\
\hline 3 & Kawanua (Minahasa People's Association) & \\
\hline \multicolumn{3}{|c|}{ Hobbies } \\
\hline 1 & Garuda Canberra (Futsal) & Welhelmus Poek \\
\hline 2 & IndoJepret Canberra (Photography) & Donny Pengjon \\
\hline 3 & GenjotI sepedACT (Cycling) & Solichin Manuri \\
\hline 4 & Canberrunners & Suharti Sutar \\
\hline \multicolumn{3}{|c|}{ Employee Sector } \\
\hline 1 & $\begin{array}{l}\text { MoFi link (Ministry of Finance Link) / civil servants from Indonesian Ministry of } \\
\text { Finance who study at ANU or UC }\end{array}$ & \\
\hline \multicolumn{3}{|c|}{ Student Dormitory } \\
\hline 1 & Indo Toadies (Indonesian Students who live in Toad Hall) & \\
\hline 2 & Jamaah Ursulawiyah (Indonesian Students who live in Ursula Hall & Miranda Tahalele \\
\hline
\end{tabular}

making it difficult to maintain neutral position, and thus influencing the position taken in the report. Another disadvantage is respondent availability. This is the perennial problem in the ethnographic approach. The researcher must also consider occasional unexpected meetings with respondents, noting the researcher also needs to make formal appointments and attend social fora. Software is also available to assist in coding and analysing interview reports but is an optional choice. By using this ethnography approach, it provides a different angle to existing Indonesian diasporic studies. Also, by taking an in-country case, the researcher can compare the level of in-depth analytical review with prior Indonesian diasporic research. 
Other research methods such as case studies, regression analysis, or library research are not applicable to the research object for this project. The number of subjects in the research sample is relatively small compared to other diasporic nationals. with only 1212 Indonesian diasporic people in Canberra. The small size of the community enables its members to come to know each other quite well. There are also many who live in the same shared house or same suburb in Canberra such as Lyneham, Dickson, or Bruce. Given this physical proximity they maintain their closeness to each other by speaking the same language.

In this research, the researcher has developed a close connection with several student groups and Muslim teaching communities in Canberra. Since the researcher is a member of the organising committee for two Indonesian students' associations, there is ready access to and ability to remain close to other Indonesian students likewise with having contact with influential Indonesian figures in the area of Muslim teachings. Two practical aspects of the ethnographic approach is conducting daily conversations and making daily observations. For this research project it can be done normally without hindrances. The common feature of these two-diasporic groups is the monthly social meeting forum. This occasionally organised as an open meeting for all members at the campus or at one of the diaspora's member's homes. One aspect of research interest is that they sometimes organise a potluck party. Indonesian traditional food comprise the main dishes. One particular issue for the Indonesian diaspora concerns halal food. This is quite challenging for Indonesian Muslim who live in a secular environment. Therefore, the sharing of halal Indonesian food maintains the practice of religious teachings and abates home-sickness. Another related issue is the language barrier. This is particularly so for the student's family members. Their level of English language fluency can pose a significant problem here for example, sometimes they are unable to answer questions when a neighbour asks something in English. This is recurring issue for those who are speakers of English as a second language which creates challenging situations for them.

This researcher also faces a cultural barrier in accessing other ethnic groups within the diaspora by being able to directly attend their social meetings. Nevertheless, access is available through friends who belong to other ethnic groups. With their assistance, the researcher can join their social meetings. However, for other groups online ethnography research is conducted through observing photographs posted on several social media platforms. A particular interesting ethnographic phenomenon observed is strong kinship relations. This often occurs in ethnic meetings here. Batak and Acehnese people invariably organise separate gatherings to other Indonesian groups. This means that their motivation is to build up their internal ethic relations rather than national identity. Cultural aspects peculiar to the ethnic group are shared at these gatherings. For example, Batak people have a tradition of eat pork and wine during their meeting. Also, they are mostly Christians. Similar to Batak people, Acehnese people also have distinctive social meetings. They are the devout Muslim believers. The Acehnese people sometime organise Qur'an recitations maintaining this tradition as most Acehnese people do in their home province.

The findings in this paper highlight the importance of family ties which broadly correlates with previous studies on Asian diasporic communities, especially Indians and Chinese people. Consistent with these studies, this study on the Indonesian diasporic in Canberra, shows that connexion to family, which are based on common religion and ethnicity, is the main reason why Asian diasporic communities tend to be inward looking rather than outward looking and embracing a western lifestyle in their host country. However, there is one notable difference between the Asian diasporic communities and the Indonesian diaspora. Indonesia's many ethnic groups also shape different home-oriented feelings. The strong local native roots still dominate home-oriented feelings rather than Indonesia as a country solely defining this feeling towards home.

\section{CONCLUSION}

Ethnography is the most appropriate research method to use in analysing diaspora. This method overcomes shortcomings in the methods used in previous diasporic research, for example by not collecting data from an insider's view and making biased interpretations. Meanwhile, prior studies have focused on the macro level, such as political and legal matters. These two perspectives do not adequately explain the real situation of the diaspora in foreign countries.

One of the most interesting findings in this study was that the life of Indonesian diasporic members is almost identical to that of their fellow Indonesians back home. This suggests that whatever happens in Indonesia will ultimately affect the Indonesian diaspora. Most importantly, among members of the Indonesian diaspora, identity essentially shapes one's feelings towards their home. These are contributing factors as to how Indonesian diasporic people express their feelings regarding their 
home while overseas.

The ethnographic method, encompassing active participation in several groups and direct observation, was the best method of researching this selected sample, the Indonesian diaspora in Canberra. Their sense of home orientation has led to them creating a 'little Indonesia' while living in Canberra. It should be noted that a key limitation of this study is that it does not cover all of the Indonesian diaspora. This consequently leaves open the opportunity for further research into this community.

\section{ACKNOWLEDGEMENT}

I would like to thank Dr Katrin Travouliion (ANU College of Asia and the Pacific Affairs) for her feedback on an earlier draft of this paper and David Rawson for his proofreading service.

\section{ENDNOTES}

1) I got this information from my past participation as an enumerator from credible Indonesian polling survey institution in Jakarta. I was hired to observe the voting process for overseas Indonesian voters in Canberra during 2019 election, last April.

\section{REFERENCES}

ACT, P. (n.d.). Komunitas Indonesia di Canberra. Retrieved 5 November 2019, from https://ppiaact.wordpress. com/informasi-act/komunitas-indonesia-di-canberra/

Brocket, T. (2018). From "in-betweenness" to "positioned belongings": Second-generation PalestinianAmericans negotiate the tensions of assimilation and transnationalism. Ethnic and Racial Studies. https:// doi.org/10.1080/01419870.2018.1544651

Bruneau, M. (2010). Diasporas, transnational spaces and communities. In R. Bauböck \& T. Faist (Eds.), Diaspora and Transnationalism (pp. 35-50). Amsterdam University Press; JSTOR. http://www. jstor.org/stable/j.ctt46mz31.5

Cohen, R. (n.d.). Diasporas and The State: From Victims to Challengers. International Affairs, 72(3), 507-520.

Dewansyah, B. (2019). Indonesian Diaspora movement and citizenship law reform: Towards 'semi-dual citizenship. 12(1), 52-63.

Gruen, E. S. (2016). Diaspora and Homeland. In The Construct of Identity in Hellenistic Judaism (1st ed., pp. 283-312). De Gruyter; JSTOR. http://www.jstor. org/stable/j.ctvbkjxph.18

Hammersley, M. (2006). Ethnography: Problems and prospects. Ethnography and Education, 1(1), 3-14. https://doi.org/10.1080/17457820500512697

Hill, D. (2014). Indonesian Political Exiles in the USSR. Critical Asian Studies, 46(4), 621-648. https://doi. org/10.1080/14672715.2014.960710

Kranson, R. (2012). Reconceptualizing Diaspora. Journal of American Ethnic History, 31(3), 77-79. JSTOR. https://doi.org/10.5406/jamerethnhist.31.3.0077

Nurse, K. (2018). Migration, Diasporas, Remittances and the Sustainable Development Goals in Least Developed Countries. Journal of Globalization and Development, 9(2), 2019-0006. https://doi.org/ doi:10.1515/jgd-2019-0006

O’ Reily, K. (2004). Ethnographic Methods. London. Routledge.

Patterson, R. (2006). Transnationalism: Diaspora-Homeland Development. Social Forces, 84(4), 1891-1907.

Reeves, S., \& Ayelet, K. (2008). Qualitative research methodologies: Ethnography. BMJ, 337, 512-514. https://doi.org/doi: https://doi.org/10.1136/bmj. a 1020

Setijadi, C. (2017). Harnessing the Potential of the Indonesian Diaspora (No. 18; Trends in Southeast Asia). ISEAS.

Sheffer, G. (n.d.). Integration impacts on Diaspora-homeland relations. Diaspora Studies, 6(1), 13-30. https://doi. org/10.1080/09739572.2013.843289

Silvey, R. (2004). Transnational domestication: State power and Indonesian migrant women in Saudi Arabia. Political Geography, 23.

Sinatti, G., \& Horst, C. (2014). Migrants as agents of development: Diaspora engagement discourse and practice in Europe. Ethnicities, 15(1), 134-152. https://doi.org/10.1177/1468796814530120

Wofford, T. (2016). Whose Diaspora? Art Journal, 75(1), 74-79. 